FACTA UNIVERSITATIS

Series: Physical Education and Sport Vol. 15, No 3, 2017, pp. 481 - 491

https://doi.org/10.22190/FUPES1703481U

Original research article

\title{
THE EFFECTS OF KINDERGARTEN SPORTS SCHOOL ON BILATERAL COORDINATION OF PRESCHOOL AGE CHILDREN
}

\author{
UDC 796:372.6
}

793.012 .2

\section{Slavoljub Uzunović ${ }^{1}$, Nenad Đorđević ${ }^{1}$, Dušan Nikolić ${ }^{1}$, Dejan Stošić ${ }^{2}$, Jovan Marković ${ }^{3}$, Vladan Petrović ${ }^{4}$, Lora Kostić ${ }^{1}$ \\ ${ }^{1}$ Faculty of Sport and Physical Education, University of Niš, Niš, Serbia ${ }^{2}$ Faculty for Sport and Physical Education, University of Priština, Leposavić, Serbia \\ ${ }^{3}$ Teachers Training Faculty in Užice, University of Kragujevac, Užice, Serbia \\ ${ }^{4}$ Faculty of Mechanical Engineering, University of Niš, Niš, Serbia}

\begin{abstract}
The research was conducted with the aim of determining to what extent and in what manner the kindergarten sports school program affects the coordination of preschool children. The sample consisted of 57 preschool age children. The control group comprised 31 children and the experimental one 26 children, aged 6 years \pm 6 months. The experimental group applied the sports school program for a period of 8 weeks $(2 \times 45$ minutes each week). The control group only had regular activities in the kindergarten. The level of bilateral coordination in children was determined applying seven tests and a level of balance applying nine tests at the initial and final measurement. At the initial measurement, experimental and control groups showed similar results, while the experimental group showed significantly better results at the final measurement. The tests applied in the research were taken from the BOT-2 battery of tests: the Bruininks-Oseretsky test of Motor Proficiency (Bruininks, 1987; Bruininks and Bruininks, 2005, taken from Cools et al, 2009), where body coordination as a separate composite is assessed by subtests of bilateral coordination and balance. The obtained data were processed by the SPSS 20 statistics software, and ANCOVA was used to determine the effects of the sports school program. It is assumed that the experimental program has influenced the improvement of the results between two assessments of the bilateral coordination (on three tests) and balance estimates (on one test). The obtained results point to the need for a wider application of similar programs in working with preschool age children.
\end{abstract}

Key words: coordination, BOT - 2, children, physical activity

Received July 10, 2017/ Accepted January 15, 2018

Corresponding author: Nenad Đorđević

Faculty of Sport and Physical Education, University of Niš, St. Čarnojevića 18, 18000 Niš, Serbia

Phone: +381 18 510900•E-mail: nesi_djordjevic@yahoo.com 


\section{INTRODUCTION}

General Motor Coordination (GMC) is considered to be one of the major elements of motor abilities in children, their cognitive abilities and psychological traits (Gallahue, Ozmun, \& Goodway, 2011). Children's GMC status depends on both biological and maturation factors (Malina, Bouchard, \& Bar-Or, 2004), as well as the environmental impact (Bouchard, Malina, \& Pérusse, 1997 according to Chaves et al., 2015). The motor function of small children is of the general type (Ismail, \& Gruber, 1971; Bala, 1981; Bala, \& Popović, 2007; Bala, Jakšić, \& Popović, 2009), which means that at that age there are no differentiated motor skills. Although still inadequately differentiated, motor skills of children can be influenced by programmed exercises, as the application of various physical exercise content improves performance in all motor skills tests (Hraski, \& Živčić, 1996a; Kostić, Miletić, Jocić, \& Uzunović, 2002; Dobrila, Sporis, \& Hraski, 2003; Deli, Bakle, \& Zachopolou, 2006; Iivonen, Nissinen, Saakslahti, Liukkonen, 2007; De Privitellio, Caput-Jogunica, Gulan, \& Boschi, 2007; Živčić, Trajkovski-Višić, \& Sentderdi, 2008), especially on coordination, flexibility and strength tests (Hraski, \& Živčić, 1996b). Coordination (Metikoš, Marković, Prot, \& Jukić, 2003), as the ability to control the movements of the whole body, or parts of the locomotor apparatus, participates in the realization of practically every movement structure, from the simplest to the most complex forms of movement, and is of great importance for the formation of a better motor base in the period of up to 7 years. It is characterized by the fast resolution of motor problems and fast and precise execution of complex motor tasks. As such, it is called "motor intelligence" (Pržulj, 2000). Children's GMC correlate with physical fitness, physical activity, as well as weight status and body composition in childhood (Cattuzo, Dos Santos Henrique, Re, \& Oliveira, 2014; D'hondt et all., 2011; Holfelder, \& Schott, 2014; Lubans, Morgan, Cliff, Barnett, \& Okely, 2010), which emphasizes the importance of systematic application of exercise in preschool age so that these factors positively affect coordination and other motor skills. Given that the societal impact is associated with the development of GMC (Chaves et al., 2015), early and varied movement experiences, teaching, adequate space and a positive attitude of parents, educators and others can significantly enhance the optimal motor development of children (Đorđić, 2006).

The compulsory physical activity performed in preschool and school institutions is not sufficient to influence the increase in the overall physical activity of the child and the improvement of his physical fitness (Cleland, Dwyer, Blizzard, \& Venn, 2008; Sallis et al., 1997; Pate, McIver, Dowda, Brown, \& Addy, 2008), and hence the demand for additional engagement of children in sports schools that would have a more comprehensive impact on the motor and psycho-physical development of children.

Sports schools, as one form of the organized physical exercise of small children, is based on the learning and development of fundamental motor skills and basic skills from various sports branches. 
The work program of the sports school consists of various means of physical exercise which in relation to the effects on the psycho-somatic status of a child (Bala, 2007) can be roughly divided into: means that affect the overall development of child organism (natural forms of movement and floor and apparatus exercises); the means affecting the development of children's motor skills (shaping exercises and apparatus exercises); means which enhance the development of functional, motor abilities and sense of the rhythm (dance choreography elements of ballet and aerobic); natural forms of movement with music or tact beats and resources that influence the development of cognitive and conative characteristics (elementary games, sports games and martial arts). Since sports schools do not prepare future athletes for certain sports disciplines, but just promote the potential to significantly contribute to the development of children's fundamental motor and physical characteristics, which are a necessary factor for participation in sports activities and everyday life activities, the authors of this paper aimed to determine how much physical exercise in the sport school influences the development of motor abilities of preschool boys as compared with the development of motor skills of the boys involved in a regular program of physical exercise as part of their preschool institutions curriculum. Therefore, the aim of this study was to determine how the program of sport school affected the coordination of the preschool children.

\section{METHODS}

\section{The sample of participants}

The sample of participants in this research consisted of children of a preschool age from the kindergarten "Naše dete" from Vranje. The children included in the "School of Sport" were recruited from all kindergartens (7 kindergartens in the town), "Pčelica" $(n=3)$, "Naše dete" $(n=3)$, "Neven" $(n=3)$, "Sunce" $(n=3)$, "Dečja radost" $(n=3)$, "Čarolija" (n=4) and "Boško Buha" $(n=7)$, while the children who comprised the control group were from the "Boško Buha" kindergarten ( $\mathrm{n}=31$ children). The total sample of participants in this study consisted of 57 boys and girls aged 6 years ( \pm 6 months). The children who were included in the "School of Sport" were included into a program implemented by a professional - a physical education teacher, while the control group was only included in the regular program in the kindergarten. The participants' parents as well as the kindergarten management were familiar with the research goal, after which they signed the agreement that the children could be involved in the research.

\section{Variable sample}

According to the BOT-2 test, body coordination as a separate composite is assessed applying the following subtests: bilateral coordination and balance. 


\section{Tests for assessing bilateral coordination}

1. Jumping in place - opposite sides synchronized,

2. Tapping feet and fingers - opposite sides synchronized,

3. Pivoting thumbs and index fingers,

4. Jumping jacks,

5. Jumping in place - same sides synchronized,

6. Touching nose with index fingers- eyes closed,

7. Tapping feet and fingers- same sides synchronized.

\section{Tests for assessing balance}

1. Standing with feet apart on a line - eyes open;

2. Walking forward on a line;

3. Standing on one leg on a line - eyes open;

4. Standing with feet apart on a line - eyes closed;

5. Walking forward heel-to-toe on a line;

6. Standing on one leg on a line - eyes closed;

7. Standing on one leg on a balance beam - eyes open;

8. Standing heel-to-toe on a balance beam;

9. Standing on one leg on a balance beam - eyes closed.

The team that performed the measurement consisted of the person performing the measurements and the person who coordinated all the time while the measurement lasted. The results were entered by the person who performed the measurement by recording better results from two attempts (two attempts were done), the result was written down into the prepared list each measurer was provided with. In the BOT-2 manual, the scoring method was explained in detail, and the measurers were fully aware of the grading and scoring methods.

\section{Data processing}

Data processing was performed by the SPSS 20. The basic central and distribution parameters were calculated: Arithmetic means, Skewness, Kurtosis, Minimum and maximum value, Standard deviation. Univariate analysis of covariance (ANCOVA) is used for determening effectiveness of two different programs on the coordination of preschool children.

\section{RESULTS}

The univariant analysis of covariance compared the effectiveness of two different programs on the coordination of preschool children. An independent variable was a binomial variable, used to classify the participants into two groups:

- a group of sports schools that underwent a program implying the development of fundamental motor skills and basic skills from various sports branches

- a control group in which children had normal daily activities of children in preschool institution without a special program. 
Table 1 Univariate analysis of covariance of sports school and control group on the final testing

\begin{tabular}{|c|c|c|c|c|c|c|c|}
\hline Variables & Group & $\mathrm{N}$ & $\begin{array}{l}\text { Mean } \\
\text { Init. }\end{array}$ & $\begin{array}{l}\text { Mean } \\
\text { Fin. }\end{array}$ & $\mathrm{F}$ & $\mathrm{p}$ & $\begin{array}{l}\text { Partial Eta } \\
\text { Squared }\end{array}$ \\
\hline \multirow{2}{*}{$\begin{array}{l}\text { Touching nose with } \\
\text { index fingers-eyes closed } \\
\text { (number of correct tries) }\end{array}$} & Control & 31 & 2.32 & 2.74 & \multirow[t]{2}{*}{1.116} & \multirow[t]{2}{*}{.295} & \multirow[t]{2}{*}{.020} \\
\hline & Sports school & 26 & 1.92 & 2.96 & & & \\
\hline \multirow{4}{*}{$\begin{array}{l}\text { Jumping jacks } \\
\text { (number of correct tries) } \\
\text { Jumping in place-same } \\
\text { sides synchronized } \\
\text { (number of correct tries) }\end{array}$} & Control & 31 & 1.58 & 1.70 & \multirow[t]{2}{*}{11.965} & \multirow[t]{2}{*}{.001} & \multirow[t]{2}{*}{.181} \\
\hline & Sports school & 26 & 2.12 & 2.62 & & & \\
\hline & Control & 31 & 1.71 & 1.84 & \multirow[t]{2}{*}{8.716} & \multirow[t]{2}{*}{.005} & \multirow[t]{2}{*}{.139} \\
\hline & Sports school & 26 & 1.65 & 2.35 & & & \\
\hline \multirow{2}{*}{$\begin{array}{l}\text { Jumping in place- } \\
\text { opposite sides } \\
\text { synchronized } \\
\text { (number of correct tries) }\end{array}$} & Control & 31 & 0.94 & 1.77 & \multirow[t]{2}{*}{6.590} & \multirow[t]{2}{*}{.013} & \multirow[t]{2}{*}{.109} \\
\hline & Sports school & 26 & 0.92 & 2.31 & & & \\
\hline \multirow{2}{*}{$\begin{array}{l}\text { Pivoting thumbs and } \\
\text { index fingers } \\
\text { (number of correct tries) }\end{array}$} & Control & 31 & 1.16 & 2.06 & \multirow[t]{2}{*}{0.147} & \multirow[t]{2}{*}{.703} & \multirow[t]{2}{*}{.003} \\
\hline & Sports school & 26 & 1.23 & 2.19 & & & \\
\hline \multirow{2}{*}{$\begin{array}{l}\text { Tapping feet and fingers- } \\
\text { same sides synchronized } \\
\text { (number of correct tries) }\end{array}$} & Control & 31 & 2.42 & 3.35 & \multirow[t]{2}{*}{2.047} & \multirow[t]{2}{*}{.158} & \multirow[t]{2}{*}{.037} \\
\hline & Sports school & 26 & 3.04 & 3.85 & & & \\
\hline \multirow{2}{*}{$\begin{array}{l}\text { Tapping feet and fingers- } \\
\text { opposite sides } \\
\text { synchronized } \\
\text { (number of correct tries) }\end{array}$} & Control & 31 & 1.32 & 1.26 & \multirow[t]{2}{*}{1.835} & \multirow[t]{2}{*}{.181} & \multirow[t]{2}{*}{.033} \\
\hline & Sports school & 26 & 1.38 & 1.77 & & & \\
\hline \multirow{2}{*}{$\begin{array}{l}\text { Standing with feet apart } \\
\text { on a line - eyes open (s) }\end{array}$} & Control & 31 & 3.81 & 3.81 & \multirow[t]{2}{*}{3.956} & .052 & .068 \\
\hline & Sports school & 26 & 3.65 & 4.00 & & & \\
\hline $\begin{array}{l}\text { Walking forward on a } \\
\text { line }\end{array}$ & Control & 31 & 3.94 & 3.87 & 0.446 & .507 & .008 \\
\hline (number of correct steps) & Sports school & 26 & 3.73 & 3.92 & & & \\
\hline Standing on one leg on a & Control & 31 & 2.29 & 2.90 & 3.281 & .076 & .057 \\
\hline line - eyes open (s) & Sports school & 26 & 2.62 & 3.38 & & & \\
\hline Standing with feet apart & Control & 31 & 2.74 & 3.39 & 2.526 & .118 & .045 \\
\hline on a line - eyes closed (s) & Sports school & 26 & 2.58 & 3.62 & & & \\
\hline Walking forward heel-to- & Control & 31 & 3.35 & 3.58 & 0.026 & .873 & .000 \\
\hline $\begin{array}{l}\text { toe on a line (number of } \\
\text { correct steps) }\end{array}$ & Sports school & 26 & 3.38 & 3.62 & & & \\
\hline Standing on one leg on a & Control & 31 & 2.23 & 2.03 & 0.700 & .406 & .013 \\
\hline line - eyes closed (s) & Sports school & 26 & 1.92 & 2.12 & & & \\
\hline Standing on one leg on a & Control & 31 & 0.13 & 0.06 & 0.846 & .362 & .015 \\
\hline $\begin{array}{l}\text { balance beam - eyes } \\
\text { open (s) }\end{array}$ & Sports school & 26 & 0.19 & 0.15 & & & \\
\hline Standing heel-to-toe on a & Control & 31 & 0.32 & 0.81 & 1.549 & .219 & .028 \\
\hline balance beam (s) & Sports school & 26 & 0.46 & 0.65 & & & \\
\hline Standing on one leg on a & Control & 31 & 0.35 & 0.29 & 0.996 & .323 & .018 \\
\hline $\begin{array}{l}\text { balance beam - eyes } \\
\text { closed (s) }\end{array}$ & Sports school & 26 & 0.35 & 0.42 & & & \\
\hline
\end{tabular}

Legend: G - group; N - number of respondents; Mean (In.) - the mean value of the initial measurement; Mean (Fin.) - the mean value of the final measurement; $F$ - the value of F-test to test the significance of differences of arithmetic means; $p$ - coefficient of significance of differences of arithmetic means; P.Eta Squ. (Partial Eta 
The dependent variable comprised the results on tests for bilateral coordination evaluation, and the results on balance check test. Preliminary checks have established that the assumptions about the normality, linearity, homogeneity of the variation, homogeneity of regression slopes and reliability of covariance measurement have not been violated. After neutralizing the evident differences during the initial testing, it can be concluded that there is a statistically significant difference at the univariate level between the participants of the sports school and control group, after experimental treatment administration, on the following tests:

- JUMPING JACKS, F=11,965, $\mathrm{P}=0,001$, where significantly better results have been achieved by the group of sports schools. Based on the eta square (Eta Squared $=0.181$ ) it can be noted that the impact of the experimental treatment is high. According to Kohen, 0.01 - is a small impact, 0.06 - is a mean influence, 0.14 and higher - is a great influence (Pallant, 2011);

- JUMPING IN PLACE - SAME SIDES SYNCHRONIZED, F=8,716, p=0,005, where significantly better results have been achieved by the group of sports schools. Based on the eta square (Eta Squared=0,139) it can be noted that the impact of experimental treatment is medium;

- JUMPING IN PLACE - OPPOSITE SIDES SYNCHRONIZED, F=6,590, $\mathrm{p}=0,013$, where significantly better results have been achieved by the group of sports schools. Based on the eta square (Eta Squared=0,109) it can be noted that the impact of experimental treatment is medium;

- STANDING WITH FEET APART ON A LINE - EYES OPEN, F=3,956, $\mathrm{p}=0,052$, where significantly better results have been achieved by a group of sports schools. Based on the eta square (Eta Squared=0,068) it can be noted that the impact of experimental treatment is high.

It can be noted that the experimental program has enhanced the improvement of the results between two tests in assessing the bilateral coordination of children, in three tests: in jumps, jumping in place same side synchronized and jumping in place opposite side synchronized, and in assessing the balance on the test standing with feet apart on a line eyes open.

\section{DISCUSSION}

The most favorable period for the development of motor abilities in children is from the age of four to twelve (Kurelić et al., 1975; Bala, 1981; Stojiljković, 2003). The age from 4 to 5 is a period suitable for the overall development of some motor skills and the improvement of body characteristics. Preschool age determines the existence of certain periods of development, so-called sensitive phases, in which the growth of certain motor skills can be expected to the greatest extent possible. In addition to the improvements of motor abilities observed by many authors (Iivonen et al., 2007; Živčić et al., 2008; Savičević, Sugović, \& Dragić, 2012) the application of the organized physical activity at this age is also significant because of the positive impact on growth and development, or child's health in general (De Privitellio et al., 2007). 
Regardless of the content that was applied, all the research in which some kind of experimental treatment of physical activity in preschool age was carried out, resulted in the improvement of certain motor skills, among other things coordination and balance. (Rodić, \& Cvejić, 2011; Hraski, \& Živčić, 1995; Iivonen et al., 2007; Hraski, Stojsavljević, \& Hraski, 2009; Rodić, 2010). Even the increase in the total volume of physical exercise, with the same activities that are applied as part of the school program, has positively influenced the improvement of motor skills of children (Savičević et al., 2012).

In this study, similar results were obtained as in other available research. The application of the experimental program of the sports school improved the results in three variables of coordination and one variable of balance. The coordination variables in which statistically significant changes occurred were jumps, jumping in place same and opposite side synchronized. Statistically significant changes can be explained by the fact that dance activities involve a large number of hops and jumps that are part of a specific dance technique, hence a positive influence on the above-mentioned variables. Every dance training requires continuous repetition of dance elements with various types of hops and jumps, so we can assume that the adoption of dance figures and movement automation lead to better results in these variables similar to the dance technique.

Dance steps also require constant changes in posture and position, whereby it is necessary to control the movement of the body's center of mass in dynamic and static actions, so that it is an understandable result of statistically significant changes in favor of balance. Kostic et al. (2002) came to similar results in their research which monitored the influence of dance content on the motor skills of boys and girls aged six to seven. The application of dance programs in preschool age implies that the dancing steps that are being conducted aim at developing basic motor skills and locomotor skills, types of hops, jumps, spinning in the space, and the like, all along following the rhythm of music in order to, among other things, develop coordination in rhythm. Positive results of the study were also obtained by Deli et al. (2006) who applied experimental treatment with a lot of programmed movements and music where the performance of the experimental groups was better than the control group. Activities of a more complex type with diverse content and the application of a greater number of motor skills such as used in sports school, or the use of polygons with different forms of movement contribute to the more versatile development of children's motor skills. The children who attended sports school in relation to the one attending regular program of physical activity had higher quality motor skills as compared to their peers (Popović, \& Stupar, 2011). The application of the polygon has also proved to be very good, given the fact that by applying different activities children received excellent stimulus, which was manifested by better performance of motor actions and improved motor skills (Mesaros-Živkov, \& Markov, 2008).

Most authors agree that despite the differences between boys and girls there is still a lot in common, and that the relationship between motor skills and cognitive dimensions at that age is very similar (Planinsec, 2002; Kosinac, \& Katić, 1999). For this reason, physical activity of boys and girls can be carried out jointly in kindergartens and preschool institutions (Bala, 2007), since activities in the field of physical education in preschool age have greater effects on the development of coordination, flexibility and balance when implemented in so called nursery and younger age as compared to the activities carried out by the so-called oldest age to the enrollment in elementary school (Sabo, 2003). 
Continuous and programmed physical activity in preschool age is an imperative and should not be left to the ad hoc movement activities, on the contrary, the movement activities must be precisely programmed with the contents of elementary games and natural forms of movement. (Redžić, Mehinović, Goletić, \& Bilalić, 2011). Previous research confirms the results of various authors who emphasized the importance and advantages of performing organized physical activity, and in particular of dance, for improving the morphological and motor characteristics of children, especially preschool and junior school age children (Madić, Mikalački, \& Popović, 2008; Madić, Popović, \& Kaličanin, 2009; Popović, 2010; Uzunović, Kostić, \& Živković, 2010)

\section{CONCLUSION}

Based on the large number of studies, we can conclude that preschool age is a very sensitive period in the development of children when it is necessary to apply activities that will enhance both motor and anthropological development of children and cognitive abilities. This suggests that physical education in preschool institutions should not be just an educational component for children to become disciplined or acquire some motor information, but it should present a deliberate process in which children are involved in a systematic and programmed exercise process. The applied sport school program certainly falls into this kind of activity and has a favorable effect on the development of bilateral coordination, and balance to a certain extent. However, additional research is needed to demonstrate that some other motor activities would cause major changes in bilateral coordination and balance for a longer period of time.

\section{REFERENCES}

Bala, G. (1981). Struktura i razvoj morfoloških dimenzija dece SAP Vojvodine (Structure and development of morphological dimension of children of SAP in Vojvodina). University of Novi Sad: Faculty of Physical Culture. In Serbian

Bala, G. (2007). Morfološke karakteristike predškolske dece (Morphological characteristics of preschool children). In: G. Bala (Ed.), Antropološke karakteristike i sposobnosti predškolske dece (Anthropological characteristics and abilities of preschool children) (pp. 31-66). University of Novi Sad: Faculty of Sport and Physical Education. In Serbian

Bala, G., \& Popović, B. (2007). Motoričke sposobnosti predškolske dece (Motor abilities of preschool children). In: G. Bala (Ed.), Antropološke karakteristike i sposobnosti predškolske dece (Anthropological characteristics and abilities of preschool children) (pp. 101-151). University of Novi Sad: Faculty of Sport and Physical Education. In Serbian

Bala, G., Jakšić, D., \& Popović, B. (2009). Trend relacija morfoloških karakteristika i motoričkih sposobnosti dece (Trend of relations between morfological characteristics and motor abilities of preschool children). In: G. Bala (Ed.), Relacije antropoloških karakteristika $i$ sposobnosti predškolske dece (Relations of anthropological characteristics and abilities of preschool children), (pp. 61-112). University of Novi Sad: Faculty of Sport and Physical Education. In Serbian

Bouchard, C., Malina, R.M., \& Pérusse L. (1997). Genetics of Fitness and Physical Performance. Champaign, IL, USA: Human Kinetics.

Cattuzzo, M.T., Dos Santos Henrique, R., Re, A..H., \& De Oliveira, I.S. (2014). Motor competence and health related physical fitness in youth: A systematic review. Journal of Science and Medicine in Sport, 19(2), 123-129. 
Chaves, R., Baxter-Jones, A., Gomes, T., Souza, M., Pereira, S., \& Maia, J. (2015). Effects of individual and school-level characteristics on a child's gross motor coordination development. International Journal of Environmental Research and Public Health, 12(8), 8883-8896.

Cleland, V., Dwyer, T., Blizzard, L., \& Venn, A. (2008). The provision of compulsory school physical activity: Associations with physical activity, fitness and overweight in childhood and twenty years later. International Journal of Behavioral Nutrition and Physical Activity, 5(1), 14.

D’hondt,VA., Deforche,B., Vaeyens, B., Vandendriessche, J., Pion, J., Philippearts, de Bourdeaudhuj, I., \& Lenoir, M. (2011). Gross motor coordination in relation to weight status and age in 5- to 12-year-old boys and girls: a cross-sectional study. International Journal of Pediatric Obesity, 6(2-2), e556-556.

De Privitellio, S., Caput-Jogunica, R., Gulan, G., \& Boschi, V. (2007). Utjecaj sportskog programa na promjene motoričkih sposobnosti predškolaca (Influence of sports program on the changes in motor abilities of preschool children). Medicina, 43(3), 204-209. In Croatian

Deli, E., Bakle, I., \& Zachopoulou, E. (2006). Implementing intervention movement programs for kindergarten children. Journal of Early Childhood Research, 4(1), 5-18.

Dobrila, I., Sporiš, G., \& Hraski, Ž. (2003). Efekti jednogodišnjeg sportskog programa djece predškolske dobi u Rijeci i Zagrebu (Effects of one year sport program on preschool children in Rijeka and Zagreb). In: V. Findak (Ed.), Book of Proceedings of $12^{\text {th }}$ Summer School of Kinesiologist of Republic of Croatia "Work methods in area of education, sport and sport recreation) (pp. 50-53). Zagreb: Croatian Kinesiological Association. In Croatian

Đorđić, V. (2006). Fizička aktivnost dece predškolskog uzrasta (Physical activity of preschool children). In: G. Bala (Ed.). Fizička aktivnost devojčica i dečaka predškolskog uzrasta (Physical activity for boys and girls of preschool age) (pp. 59-73). University of Novi Sad: Faculty of Physical Culture. In Serbian

Gallahue, D., Ozmun, J., \& Goodway, J. (2011). Understanding motor development: Infants, children, adolescents, adults. São Paulo: McGraw-Hill Education.

Holfelder, B., \& Schott, N., (2014). Relationship of fundamental movement skills and physical activity in children and adolescents: a systematic review. Psychology of Sport and Exercise, 15(4), 382-391.

Hraski, M., Stojsavljević, V., \& Hraski Ž. (2009). The distributon of the development of some motor abilities in preschool boys who participated in a three-year preschool sports programme. In: I. Prskalo, V. Findak \& J. Strel (Eds.), Proceedings Book of III Special Focus Symposium on Kinesiological Education, "Heading towards the future" (pp.83-90). Zagreb: Faculty of teacher education.

Hraski, Ž., Živčić, K. (1995). Efekti eksperimentalnog jednogodišnjeg sportskog programa za predškolce (Effects of the experimental one year sports program for preschool children), In: V. Findak (Ed.), Proceedings of the 4th Summer school of physical education teachers in the Republic of Croatia, (pp. 155-156). University of Zagreb: Faculty of Physical Culture. In Croatian

Hraski, Ž., \& Živčić, K. (1996a). Mogućnost razvoja motoričkih potencijala djece predškolske dobi (Possibilities of the development of preschool children motor potentials), In: D. Milanović (Ed.), Proceedings - International Counciling on Fitness, Zagreb Sports Fair) (pp.II 12 -II 15). Zagreb: Faculty of Physical Culture.

Hraski, Ž., \& Živčić, K. (1996b). Standardizacija nekih testova za predškolsku dob (Standardizations of some motor tests for preschool age), In: D. Milannović (Ed.), Proceedings - International counciling on fitness, Zagreb Sports Fair) (pp. II 12 - II 15). University of Zagreb: Faculty of Physical Culture. In Croatian

Iivonen, S., Nissinen, K., Sääkslahti, A., \& Liukkonen, J. (2007). Effects of preschool physical education curriculum - program on 4-5 year old children's fundamental motor skill. In: A. Jones (Ed.), 12th Annual Congress of the Europien College of Sport Science. Jyväskylä: Europien College of Sport Science.

Ismail, A.H., \& Gruber, J.J. (1971). Integrated development: Motor aptitude and intellectual performance. Columbus, OH: Charles Merrill Publishing.

Kosinac, Z., \& Katić, R. (1999). Longitudinal study on the development of morphological-motor characteristics of boys and girls aged 5 to 7. Proceedings of the 2nd International Scientific Conference (pp. 144-147). Dubrovnik: Croatia.

Kostić, R.M., Miletić, Đ., Jocić, D.J., \& Uzunović, S. (2002). Influence of dance structures on motor abilities of preschool children. Facta Universitatis Series Physical Education and Sport, 1(9), 83-90.

Kurelić, N., Momirović, K., Stojanović, M., Šturm, J., Radojević, Đ., \& Viskić -Štalec, N. (1975). Struktura $i$ razvoj morfoloških i motoričkih dimenzija omladine. University of Belgrade: Faculty of Physical Education. In Serbian

Lubans, D.R., Morgan, P.J., Cliff, D. P., Barnett, L.M., \& Oakley, A.D. (2010). Fundamental movement skills in children and adolescents: Review of associated health benefits. Sports Medicine, 40(12), 1019-1035. 
Madić, D., Mikalački, M., \& Popović, B. (2008). Effects of the traditional and modern approach to physical education on obesity of girls at younger school age. In: L. Mihuţ (Ed.), Research and education in Innovation Era. International Symposium (pp. 21-9). Arad: University 'Aurel Vlaicu'.

Madić, D., Popović, B., \& Kaličanin, N. (2009). Antropometrijske karakteristike devojčica uključenih u program razvojne gimnastike (Anthropometric characteristics of girls included in program of development gymnastic). Glasnik Antropološkog društva Srbije, 44, 79-86. In Serbian

Malina, R.M., Bouchard, C., \& Bar-Or, O. (2004). Growth, maturation and physical activity. Champaign, IL, USA: Human Kinetics.

Metikoš, D., Marković, G., Prot, F., \& Jukić, I. (2003). Latent structure of agility obtained by a battery of tests. Kinesiology, 35(1), 14-29.

Pate, R.R., McIver, K., Dowda, M., Brown, W.H., \& Addy, C. (2008). Directly observed physical activity levels in preschool children. The Journal of School Health, 78(8), 438-444.

Pallant, J. (2011). SPSS survival manual: A step by step guide to data analysis using the SPSS program. Berkshire: Open University Press.

Planinsec, J. (2002). Relations between the motor and cognitive dimensions of preschool girls and boys. Perceptual and Motor Skills, 94(2), 415-423.

Popović, B. (2010). Specifičnosti antropološkog statusa devojčica školskog uzrasta - juniorki pod uticajem programa vežbanja razvojne gimnastike (Specifics of the anthropological status of junior schoolgirls influenced by programmed developmental gymnastics exercising). Doctoral Dissertation, University of Novi Sad: Faculty of Sport and Physical Education. In Serbian

Popović, B., \& Stupar, D. (2011). Efekti vežbanja po programu na razvoj motoričkih sposobnosti dečaka predškolskog uzrasta (Effects of exercising by program on the development of motor abilities of preschool boys), Glasnik Antropološkog društva Srbije, 46, 269-277. In Serbian

Pržulj, D. (2000). Antropomotorka (Anthropomotorics). Srpsko Sarajevo: Faculty of Physical Education. In Serbian

Redžić, H., Mehinović, J., Goletić, E., \& Bilalić, J. (2011). Qantitative changes in morphological characteristics and motor abilities of preschool girls. Sportski Logos, 9(16-17), 50-58.

Rodić, N. (2010). Influence of „sports playroom" on motor abilities of preschool children. Pedagogija,, 65(1), 148-158.

Rodić, N., \& Cvejić, D. (2011). Influence of different methods on the development of coordination in third grade schoolboys. Norma, 16(1), 67-79.

Sabo, E. (2003). Structure of motor space and differences in motor abilities of preschool girls at the elementary school entrance. Norma, 9(2-3), 185-196.

Sallis, J.F., McKenzie, T.C., Alcaraz, J.E., Kolody, B., Faucette, N., \& Hovell, M.F. (1997). The effects of a $2-$ year physical education program (SPARK) on physical activity and fitness in elementary school students. Sports, play and active recreation for kids. American Journal of Public Health, 87, 128-34.

Savičević, D., Suzović, D., \& Dragić, B. (2012). Transformation effect of the program model of physical activities on motor preschool children abilities. Fizička kultura, 66(2), 119-128.

Stoiljković, S. (2003). Osnove opšte antropomotorike (Basics of general anthropomotorics). Niš: Crveni krst. In Serbian

Uzunović, S., Kostić, R., \& Živković, D. (2010). Effects of two different programs of modern sport dancing on motor coordination, strengh, and speed. Medical Problems of Performing Artists, 25(3), 102-109.

Živčić, K., Trajkovski-Višić, B., \& Sentderdi, M. (2008). Changes in some of the motor abilities of preschool children (age four). Facta Universitatis Series Physical Education and Sport, 1(6), 41-50. 


\section{EFEKTI ŠKOLICE SPORTA NA BILATERALNU KOORDINACIJU DECE PREDŠKOLSKOG UZRASTA}

Istraživanje je sprovedeno sa ciljem da se utvrdi u kojoj meri i kako program školice sporta deluje na koordinaciju dece predškolskog uzrasta. Uzorak je činilo 57 dece predškolskog uzrasta. Kontrolnu grupu 31 dete, eksperimentalnu 26 dece, uzrasta od 6 godina \pm 6 meseci, Eksperimentalna grupa je realizovala program školice sporta u periodu od 8 nedelja ( $2 \times 45$ minuta svake nedelje). Kontrolna grupa je imala samo redovne aktivnosti u vrtiću. Nivo bilateralne koordinacije kod dece utvrđen je primenom sedam testova, a nivo ravnoteže primenom devet testova na inicijalnom i finalnom merenju. Na inicijalnom merenju slične rezultate pokazali su i eksperimentalna i kontrolna grupa, dok na finalnom merenju znatno bolje rezultate pokazuje eksperimentalna grupa. Testove koji su korišćeni u istraživanju su iz baterije testova BOT-2 -the Bruininks-Oseretsky test of Motor Proficiency (Bruininks, 1987; Bruininks i Bruininks, 2005, preuzeto iz Cools et al, 2009) gde se koordinacija kao poseban kompozit procenjuje uz pomoć podtestova bilateralne koordinacije i ravnoteže. Dobijeni podaci obrađeni su programom za statistiku SPSS 20, a za utvrđivanje efekta programa školice sporta korišćena je ANCOVA. Pretpostavlja se da je eksperimentalni program uticao na poboljšanje rezultata između dva testiranja procene bilateralne kordinacije (na tri testa) i procene ravnoteže (na jednom testu). Dobijeni rezultati ukazuju na potrebu šire primene sličnih programa u radu sa decom predškolskog uzrasta.

Ključne reči: koordinacija; BOT-2, deca, fizička aktivnost 